\title{
ORGANIZATIONAL TRANSFORMATION: MEMEDIASI PENGARUH INVESTASI TEKNOLOGI INFORMASI TERHADAP KINERJA ORGANISASI PADA PEMERINTAH DAERAH DI INDONESIA
}

\author{
Wiwik Supratiwi \\ wiwik.supratiwi@yahoo.co.id \\ Dian Agustia \\ Universitas Airlangga, Indonesia
}

\begin{abstract}
The purpose of this research is to examine the role of organizational transformation in mediating the effect of information technology investments on organizational performance in local governments. This research is designed as quantitative research with district or city level as unit of analysis. The research sample are 38 districts or cities in East Java province using convenience samples due to the limitations of time, cost, and access to data collection. Data used are primary data collected through questionnaires to respondents from the determined Local Government Agencies in each sample district or city. The data analysis uses SEM-PLS. It can be used for the small number of samples and can predict complex models. Data processing uses the Warp PLS 6.0 software application. This study uses the second-order construct model with reflective first-order and second-order. Variables are measured by using a 1-7 semantic differential scale. The theory used is the process theory with teleology typology. This study found that organizational transformation mediates partially the effect of IT investment on organizational performance in local governments. Future studies can use different measurements for each latent variable, different sampling method, and are expected to continue to pay attention to organizational factors.
\end{abstract}

Key words: information technology investment; organizational transformation; organizational performance

\begin{abstract}
ABSTRAK
Tujuan penelitian ini adalah untuk menguji peran organizational transformation dalam memediasi pengaruh investasi Teknologi Informasi pada kinerja organisasi di pemerintah daerah. Penelitian ini didesain sebagai penelitian kuantitatif dengan unit analisis tingkat kabupaten atau kota. Sampel penelitian adalah 38 kabupaten atau kota di provinsi Jawa Timur menggunakan convenience samples karena keterbatasan waktu, biaya, dan akses pada pengumpulan data. Data yang digunakan adalah data primer yang dikumpulkan melalui kuesioner kepada responden dari Instansi Pemerintah Daerah di setiap kabupaten atau kota sampel penelitian. Analisis data menggunakan SEM-PLS. Ini dapat digunakan untuk sejumlah kecil sampel dan dapat memprediksi model yang kompleks. Pemrosesan data menggunakan aplikasi perangkat lunak Warp PLS 6.0. Penelitian ini menggunakan model secondorder construct dengan first-order and second-order reflektif. Variabel diukur dengan menggunakan skala diferensial semantik 1-7. Teori yang digunakan adalah process theory dengan tipologi teleologi. Studi ini menemukan bahwa organizational transformation memediasi secara parsial pengaruh investasi TI pada kinerja organisasi di pemerintah daerah. Penelitian selanjutnya dapat menggunakan pengukuran yang berbeda untuk setiap variabel laten, metode pengambilan sampel yang berbeda, dan diharapkan untuk terus memperhatikan faktor-faktor organisasi.
\end{abstract}

Kata kunci: investasi teknologi informasi; organizational transformation; kinerja organisasi

\section{PENDAHULUAN}

Perkembangan teknologi informasi (TI) telah mengubah paradigma organisasi pe- merintahan. Perubahan paradigma dari birokrasi tradisional ke e-government yang berdampak pada semakin baiknya pelaya- 
nan publik. Mengacu pada Greve (2015), peran TI dalam organisasi pemerintahan dapat dikelompokkan berdasarkan arah atau kecenderungannya sebagai berikut: 1) mulai TI sebagai alat untuk efisiensi hingga sebagai bagian dari profil digital; 2) mulai TI ditinjau sebagi perspektif efisiensi hingga perspektif tatakelola digital yang memungkinkan adanya berbagi dan penyebaran informasi; 3) mulai dari manfaat TI dalam jangka pendek hingga nilai TI pada manajemen publik termasuk fokus dalam jangka panjang; 4) mulai TI terkait dengan pertanggungjawaban untuk keluaran hingga transparansi dan akuntabilitas; 5) mulai TI untuk tatakelola organisasi berdiri sendiri hingga TI untuk tatakelola organisasi yang terkait atau tergantung satu sama lainnya; dan 6) mulai TI untuk melayani masyarakat hingga masyarakat sebagai mitra inovasi layanan.

Penerapan TI tidak menghilangkan birokrasi namun sangat berperan mendukung birokrasi di sektor publik (Cordella dan Tempini, 2015). Menurut Sivarajah et al. (2015) bahwa adopsi TI pada organisasi pemerintahan belum optimal dan bahkan masih berada dalam tahap awal sehingga belum diperoleh manfaat yang diharapkan. Kondisi tersebut mendorong organisasi pemerintahan terus meningkatkan investasi TI guna memperbaiki kualitas informasi dan memungkinkan memperoleh manfaat TI yang selanjutnya dapat meningkatkan kinerja organisasi pemerintahan (Alenezi et al., 2015).

Penelitian tentang investasi TI telah banyak dilakukan dan hasilnya bervariasi (Khallaf et al., 2017; Sabherwal dan Jeyaraj, 2015). Perbedaan hasil tersebut disebabkan teori yang digunakan (Soh dan Markus, 1995) dan dipengaruhi oleh ukuran sampel, sumber data, dan industri (Sabherwal dan Jeyaraj, 2015). Menurut Baker et al. (2017) dan Peng et al. (2016) model dengan menggunakan variabel kunci yang berperan sebagai mediasi dapat menjelaskan nilai TI lebih baik daripada model tanpa mediasi.

Penelitian mengenai investasi TI di pemerintahan telah banyak dilakukan
(Alaaraj dan Ibrahim, 2014; Cordella dan Tempini, 2015; Gao, 2015; Gil-Garcia et al., 2014; Janowski, 2015; Jung, 2019; Nielsen dan Pedersen, 2014; Pang, 2014; Teryima dan Sunday, 2015). Sebagian besar penelitian TI di pemerintahan belum menghubungkan antara investasi TI dan kinerja organisasi. Maal-Gharaibeh dan Malkawi (2013) meneliti dampak Management Information Systems (MIS) pada kinerja organisasi pemerintah yang dilakukan pada Kementerian Perencanaan Jordania. Penelitian tersebut menyimpulkan bahwa hardware dan software saja tidak berdampak pada kinerja organisasi pemerintah. Jaringan, Sumber Daya Manusia (SDM), dan prosedur, serta MIS sebagai satu kesatuan berdampak signifikan pada kinerja organisasi pemerintah. Hal tersebut menunjukkan bahwa investasi TI pada organisasi pemerintahan tidak cukup hanya sekedar berupa hardware dan software saja, diperlukan pendekatan organisasional untuk meningkatkan kinerja organisasi. Berdasarkan studi kasus pada pemerintah daerah di Spanyol (Criado et al., 2017), pada pemerintah daerah di Australia (Hossan, 2015), dan implikasi dari hasil penelitian Welch dan Feeney (2014) di Amerika Serikat juga menyatakan bahwa faktor organisasional perlu dipertimbangkan dalam penerapan TI di samping faktor teknologi. Berdasarkan penelitian-penelitian terkait TI di organisasi pemerintahan tersebut mengindikasi bahwa faktor organisasional merupakan faktor penting untuk diperhatikan dan diteliti. Dampak investasi pada kinerja organisasi sektor publik akan terlihat setelah empat tahun (Kobelsky et al., 2014), meskipun dampak ini bervariasi untuk setiap organisasi.

Menurut Laudon dan Laudon (2018) terdapat faktor organisasional yang memediasi hubungan investasi TI dengan kinerja organisasi. Berdasarkan beberapa hasil penelitian yang dilakukan pada perusahaan komersial, disimpulkan bahwa investasi TI berdampak pada organizational transformation (Cha et al., 2015; Zeng et al., 2015). Hasil penelitian yang dipublikasikan 
pada Government Information Quarterly tahun 1992-2014 (Janowski, 2015) mengindikasikan bahwa penerapan TI pada organisasi pemerintah berakibat adanya proses organizational transformation. Peneliti organizational transformation harus mengaitkan antara proses perubahan dengan kinerja organisasi (Fernandez dan Rainey, 2017).

Peraturan Presiden Nomor 95 tahun 2018 tentang Sistem Pemerintahan Berbasis Elektronik mengharuskan pemerintah daerah untuk menerapkan e-government (Republik Indonesia, 2018). Pemerintah Republik Indonesia telah mengalokasikan anggaran untuk belanja TI antara tahun 2014-2016 secara nasional rata-rata sebesar $\mathrm{Rp} 4,23 \mathrm{~T}$ per tahun. Di Indonesia, berdasarkan hasil kajian Dewan Teknologi Informasi dan Komunikasi (TIK) Nasional tahun 2016 dinyatakan bahwa pemanfaatan TI di pemerintahan masih rendah, yaitu sebesar 30\% dari kapasitas yang tersedia. Hal tersebut menunjukkan bahwa efektivitas investasi TI di pemerintah daerah juga masih rendah (RI, 2018). Penelitian TI dan organizational transformation masih menarik karena peran TI dalam mendukung organizational transformation masih dipandang ambigu (Rowe et al., 2017).

Organisasi pemerintah daerah dipandang sebagai suatu proses yang selalu berubah dan berkembang (Hernes, 2014). Penelitian tentang organisasi pemerintah daerah dinilai tepat bila menggunakan teori proses. Teori proses adalah teori yang menjelaskan serangkaian peristiwa yang terjadi secara berurutan dalam organisasi, yaitu bagaimana dan mengapa suatu outcome dicapai yang berakibat pada perubahan dan perkembangan organisasi (Mohr, 1982; Van de Ven dan Poole, 1995). Peristiwa berurutan tersebut dalam penelitian dapat digambarkan sebagai model mediasi. Variabel mediasi berperan memengaruhi dampak variabel independen ke variabel dependen ( $\mathrm{O}^{\prime}$ Rourke dan MacKinnon, 2018). Analisis mediasi menjelaskan urutan dampak dari satu peristiwa yang mengarah pada sesuatu lainnya (Nitzl et al., 2016). Teori proses digunakan dalam penelitian ini karena dinilai mampu menjelaskan bagaimana, kapan, dan mengapa investasi TI meningkatkan kinerja organisasi (Soh dan Markus, 1995). Jenis teori proses yang tepat untuk penelitian ini adalah teleology (Van de Ven dan Poole, 1995). Teori proses dapat menjelaskan terciptanya outcome atas investasi TI dengan terlebih dahulu mengidentifikasi peristiwa-peristiwa yang terjadi secara berurutan pada organisasi pemerintah daerah (Burton-Jones et al., 2015).

Berdasarkan hasil penelitian terdahulu yang inkonsisten mengenai hubungan investasi Teknologi Informasi dan kinerja organisasi menunjukkan bahwa topik ini masih layak untuk diteliti. Studi ini menggunakan pendekatan analogi, yaitu dengan mengadopsi variabel organizational transformation yang terbukti berperan sebagai mediasi dalam hubungan investasi TI dengan kinerja organisasi di perusahaan komersial. Subyek penelitian menggunakan pemerintah daerah. Rumusan masalah penelitian ini adalah apakah organizational transformation memediasi pengaruh investasi TI terhadap kinerja organisasi pada pemerintah daerah?

\section{TINJAUAN TEORETIS}

\section{Teori Proses}

Teori yang digunakan dalam penelitian ini harus dapat menjelaskan fenomena dan masalah sebenarnya yang diteliti (Sharma et al., 2019). Pemilihan teori proses karena teori ini terbukti lebih unggul dibanding teori varian terkait dengan penelitian hubungan kausal TI dan nilai bisnis atau kinerja organisasi (Markus dan Robey, 1988; Soh dan Markus, 1995). Karakteristik teori proses nampak pada Tabel 1.

\section{Tabel 1}

Karakteristik Process Theory

\begin{tabular}{ll}
\hline Karakteristik & \multicolumn{1}{c}{ Uraian } \\
\hline Outcome & Kejadian yang berbeda \\
Bentuk logis & Bila bukan X (kondisi yang \\
& diperlukan) maka bukan Y \\
& (outcome). Tidak dapat diarti- \\
& kan semakin besar X maka \\
& semakin besar Y \\
\hline
\end{tabular}




\begin{tabular}{ll}
\hline Asumsi & $\begin{array}{l}\text { Outcome mungkin tidak terjadi } \\
\text { meskipun terdapat kondisi } \\
\text { yang diperlukan, kecuali } \\
\text { adanya kekuatan eksternal }\end{array}$ \\
Waktu & $\begin{array}{l}\text { Urutan waktu adalah penting } \\
\text { Penjelasan }\end{array}$ \\
teori & $\begin{array}{l}\text { Penyebab terdiri dari kondisi } \\
\text { yang diperlukan terjadi dalam }\end{array}$ \\
& $\begin{array}{l}\text { urutan tertentu dimana } \\
\text { perubahan dan peristiwa acak } \\
\text { berperan }\end{array}$ \\
\hline
\end{tabular}

Sumber: (Markus dan Robey, 1988; Mohr, 1982; Soh dan Markus, 1995)

Process theory dapat digunakan karena terdapat kesesuaian process theory dengan penelitian ini seperti yang dikemukakan Soh dan Markus (1995) adalah membantu untuk memahami bahwa investasi TI tidak selalu meningkatkan kinerja organisasi, meyediakan kerangka untuk menguji kondisi dan proses investasi TI yang terkait dengan peningkatan kinerja organisasi. Proses dalam penelitian ini adalah penjelasan hubungan kausal antar variabel independen, variabel pemediasi, dan variabel dependen. Urutan peristiwa yang menjadi prasyarat penting dalam teori proses dalam hal ini adalah: 1) investasi TI dilakukan terlebih dahulu; 2) tindakan organisasi berupa organizational transformation; 3) peningkatan kinerja organisasi pada pemerintah daerah (Van de Ven, 1992). Investasi TI akan meningkatkan kinerja organisasi pada pemerintah daerah melalui organizational transformation. Penelitian yang terkait dengan organizational transformation dinilai lebih tepat menggunakan teori berbasis proses mengingat bahwa transformasi merupakan proses yang berkelanjutan (Hossan, 2015).

Mengacu pada Van de Ven dan Poole (1995) process theory dikelompokkan menjadi empat teori atau model, yaitu life cycle, teleology, dialectic, dan evolution. Perbedaan tipologi atau model tersebut dapat dilihat dari pemicu perubahan, unit perubahan (entitas tunggal atau multi entitas), dan mode perubahan (mengikuti urutan atau diciptakan). Tipologi perubahan life cycle (regulated change) mengasumsikan bahwa perubahan pada organisasi itu akan tetap ada selamanya. Model perubahan life cycle tersebut menggambarkan tahapan proses perubahan secara berurutan dari awal hingga akhir yang terjadi pada suatu organisasi. Proses perubahan model life cycle meliputi start up, grow, harvest, dan terminate yang terjadi secara berulang-ulang. Model perubahan teleology (planned change) menggambarkan bahwa proses perubahan suatu organisasi dimulai dari adanya ketidak puasan dalam organisasi, yaitu dengan pengulangan perumusan tujuan, implementasi, evaluasi, dan pencapaian tujuan. Tipologi perubahan dialectic (conflictive change) menjelaskan bahwa proses perubahan pada organisasi ditandai munculnya peristiwa atau kekuatan yang saling bertentangan. Kondisi tersebut mengakibatkan organisasi berproses menuju keseimbangan, berada di antara dua kekuatan yang bertentangan, atau menjauh dari keseimbangan yang memungkinkan munculnya perubahan yang frontal. Tipologi perubahan evolution (competitive change) menggambarkan adanya proses evolusi yang terjadi secara bertahap dan terus menerus pada organisasi. Penggunaan evolution process theory dalam organisasi adalah untuk menggambarkan adanya peubahan populasi organisasi secara menyeluruh, perubahan penyusunan strategi, dan bahkan perubahan lainnya yang lebih kecil dalam organisasi (Van de Ven dan Poole, 1995). Tipologi perubahan teleology (planned change) merupakan model yang paling sesuai untuk investasi TI. Ditinjau dari pemicu perubahan, penyebab investasi TI dilakukan oleh pemerintah daerah adalah adanya ketidakpuasan atau kekurangan atas sistem informasi yang digunakan saat ini guna menjalankan tugas dan fungsinya. Ditinjau dari unit perubahan, jumlah entitas yang berubah terkait investasi TI hanya satu yaitu pemerintah daerah yang bersangkutan. Ditinjau dari mode perubahan, investasi TI yang dilakukan oleh pemerintah daerah memungkinkan terjadinya reformulasi entitas dan bahkan adanya bentuk baru yang belum pernah ada sebelumnya (Van de Ven dan Poole, 1995). 
Investasi Teknologi Informasi, Organizational Transformation, dan Kinerja Organisasi

Investasi TI menyebabkan adanya organizational transformation (Cha et al., 2015; Loebbecke dan Picot, 2015; Zeng et al., 2015). Investasi TI yang dilakukan secara intensif tidak hanya akan berakibat pada adanya organizational transformation tetapi juga akan memicu peningkatan kinerja organisasi (Jacobsen et al., 2017). Teknologi Informasi telah mengubah organisasi sektor publik ditinjau dari berbagai aspek seperti birokrasi, pertanggungjawaban, dan profesionalisme (Plesner et al., 2018). Demikian pula dengan Information Technology enabled Organizational Transformation juga merupakan konsep populer bagi praktisi dan peneliti TI hingga saat ini (Zeng et al., 2015). Hubungan TI dan OT telah banyak diteliti dan hasilnya masih inkonsisten (Nograšek dan Vintar, 2014). Perdebatan keterkaitan TI dengan OT terus berlanjut hingga Rowe et al. (2017) menyatakan bahwa pentingnya organisasi memiliki kemampuan menangkap sinyal lemah agar OT berjalan dengan baik disamping dapat mengakomodasi perubahan lingkungan. Investasi TI harus didukung dengan adanya organizational transformation yang memadai agar dapat meningkatkan kinerja organisasi (Coombs, 2015).

Peran TI dalam meningkatkan kinerja organisasi telah banyak diperhatikan baik oleh peneliti maupun praktisi. Investasi Teknologi Informasi dalam suatu organisasi tentu diharapkan akan meningkatkan kinerjanya. Keberhasilan implementasi TI tersebut diikuti dengan perubahan organisasi atau organizational transformation. Organisasi yang telah melakukan organizational transformation sebagai konsekuensi dari investasi TI atau dibangun berbasis TI sebagaimana hasil penelitian Nwankpa dan Roumani (2016) sangat dimungkinkan dapat meningkatkan kinerjanya. Demikian pula pemerintah daerah yang telah melakukan investasi TI memerlukan organizational transformation sebagai upaya untuk meningkatkan kinerja- nya. Berdasarkan uraian di atas dapat dirumuskan hipotesis berikut:

$\mathrm{H}_{1}$ : Terdapat pengaruh investasi teknologi informasi terhadap organizational transformation pada pemerintah daerah

Di era lingkungan yang sangat dinamis seperti saat ini, organisasi atau perusahaan dituntut untuk bergerak cepat dan tepat. Ketangkasan organisasi dapat diciptakan dengan memanfaatkan sumber daya Teknologi Informasi melalui organizational transformation (Lee, 2012). Apabila dikaitkan dengan asumsi process theory yang menyatakan bahwa outcome mungkin tidak akan diperoleh meskipun investasi TI telah dilakukan tanpa diikuti organizational transformation sebagai katalisator perubahan (Soh dan Markus, 1995). Organizational transformation tersebut juga merupakan implementasi proses perubahan yang terencana untuk mencapai tujuan yang ditetapkan, yaitu peningkatan kinerja organisasi sebagaimana digambarkan dalam model teleology (Van de Ven dan Poole, 1995). Demikian halnya dengan pemerintah daerah yang telah memutuskan belanja Teknologi Informasi sebagai belanja investasi sesuai dengan perencanaan dan penganggarannya, perlu melakukan organizational transformation untuk meningkatkan kinerja organisasi. Investasi TI berdampak positif pada organizational transformation yang selanjutnya meningkatkan kinerja organisasi.

Berdasarkan uraian di atas dapat dirumuskan hipotesis berikut:

$\mathrm{H}_{2}$ : Organizational transformation memediasi pengaruh investasi teknologi informasi terhadap kinerja organisasi pada pemerintah daerah

\section{METODE PENELITIAN}

Penelitian ini merupakan penelitian kuantitatif yang bertujuan untuk memperoleh bukti empiris peran organizational transformation dalam memediasi pengaruh investasi Teknologi Informasi dengan kinerja organisasi pada pemerintah daerah. Sampel penelitian ini adalah 38 kabupaten 
atau kota di wilayah provinsi Jawa Timur. Pengambilan sampel tersebut menggunakan convenience sample (Etikan et al., 2016) yaitu dengan mempertimbangkan keterbatasan waktu, biaya, dan akses pengumpulan data. Unit analisis penelitian ini adalah level organisasi, yaitu kabupaten atau kota.

\section{Definisi Operasional Variabel dan Pengukuran}

1) Investasi Teknologi Informasi

Investasi TI dalam penelitian ini didefinisikan sebagai ketersediaan akan hardware, software, jaringan, dan peningkatan kompetensi SDM pada pemerintah daerah terkait implementasi TI baik untuk komunikasi dan koordinasi internal maupun untuk pelayanan masyarakat atau komunikasi dengan pihak eksternal (Aral dan Weill, 2007; Smith dan McKeen, 1991). Kuesioner dikembangkan berdasar indikator pengukuran TI (Smith dan McKeen, 1991). Khusus untuk indikator kapabilitas perangkat lunak, kuesioner dikembangkan dari konstruk TI yang digunakan oleh Aral dan Weill (2007). Indikator investasi TI terdiri atas:
a. Kepemilikan perangkat keras atau hardware
b. Kapabilitas aplikasi perangkat lunak atau software
c. Jenis software berbasis teknologi internet, menurut fungsinya
d. Fitur TI
2) Kinerja Organisasi

Kinerja organisasi adalah capaian pemerintah daerah atas implementasi kegiatan untuk mencapai tujuan dan sasaran yang telah ditetapkan. Kinerja organisasi dalam penelitian ini menggunakan ukuran kinerja non keuangan. Kinerja non keuangan pemerintah daerah merupakan kinerja atas aktivitas yang dilakukan atau work performance (Yang et al., 2007). Kuesioner diadopsi dan disesuaikan dari item pertanyan untuk indikator work performance tersebut serta menambah item pertanyaan untuk indikator kemampuan memenuhi tujuan dan sasaran dari (Kuhlmann, 2010). Indikator Kinerja Organisasi terdiri atas: a. Efisiensi operasional

b. Ketaatan pada jadwal

c. Kecepatan penyelesaian pekerjaan

d. Kepatuhan pada anggaran

e. Jumlah aktivitas

f. Kemampuan memenuhi tujuan dan sasaran

3) Organizational Transformation

Organizational transformation yang terjadi pada pemerintah daerah adalah perubahan organisasi yang bersifat mayor. Perubahan mayor tersebut terkait dengan perubahan yang terjadi dalam melaksanakan aktivitasnya. Kuesioner untuk mengukur organizational transformation pada pemerintah daerah dalam penelitian ini dikembangkan dari mengadopsi indikator yang digunakan oleh Romanelli dan Tushman (1994). Indikator organizational transformation tersebut meliputi perubahan strategi, perubahan struktur, dan perubahan distribusi kekuasaan.

4) Ukuran Organisasi Pemerintah Daerah Mengacu pada Peraturan Pemerintah Republik Indonesia Nomor 18 tahun 2016 tentang Perangkat Daerah (RI, 2016), salah satu ukuran organisasi pemerintah daerah ditetapkan berdasar besaran nilai Anggaran Pendapatan dan Belanja Daerah (APBD). Penentuan dasar ukuran pemerintah derah dalam peraturan tersebut telah melalui kajian akademik. APBD dapat digunakan karena telah disahkan oleh DPRD dan telah ditetapkan dalam Peraturan Daerah. Semakin besar APBD suatu daerah maka dinyatakan semakin besar pula ukuran daerah yang bersangkutan. Besaran nilai APBD lebih tepat digunakan sebagai ukuran organisasi daripada luas wilayah atau jumlah penduduk. Hal ini disebabkan besaran APBD lebih mencerminkan tanggung jawab pengelolaan daerah.

\section{Pengukuran}

Pengukuran variabel menggunakan skala semantic differential. Skala semantic differential ini mampu mengukur penilaian responden mengenai konstruk ditinjau dari multidimensi. Setiap pertanyaan tersedia dua jawaban yang berlawanan atau disebut 
bipolar namun merupakan satu rangkaian yang terbentang dalam peringkat pilihan jawaban 1 sampai dengan 7 (Hair et al., 2014). Angka 1 menunjukkan intensitas tinggi adanya persepsi unfavorable dan angka 7 menunjukkan intensitas tinggi adanya persepsi favorable. Angka 4 yang berada di tengah menunjukkan persepsi netral terhadap obyek persepsi. Data APBD sebagai variabel kontrol dinyatakan dalam logaritma natural (Ln) dengan tujuan untuk menurunkan variansi antar data yang diolah.

\section{Prosedur Pengumpulan Data}

Penelitian ini menggunakan pilot test, yaitu mengumpulkan data dalam jumlah kecil dari responden yang sama dengan survei yang sebenarnya (Zikmund et al., 2017). Tujuan dari pilot test ini adalah untuk memastikan bahwa kuesioner yang digunakan benar-benar dapat digunakan sebagai instrumen penelitian. Data diperoleh dari penyebaran kuesioner kepada responden di seluruh kabupaten atau kota sampel. Setiap daerah diwakili oleh responden dari Perangkat Daerah yang telah ditentukan. Pemilihan tersebut mempertimbangkan keterwakilan dari tiga jenis perangkat daerah (Dinas, Badan, Sekretariat) serta memiliki keterkaitan dengan investasi dan kebijakan TI sekaligus sebagai pengguna. Kecamatan tidak dipilih karena lingkup tanggung jawabnya paling kecil dibanding perangkat daerah lainnya. Perangkat daerah yang dipilih tersebut meliputi Badan Perencana Pembangunan Daerah atau Badan Perencana Pembangunan Kota (Bappeda atau Bappeko), Badan Pengelola Keuangan dan Aset Daerah (BPKAD), Biro Administrasi Pembangunan pada Sekretariat Daerah, serta Dinas Komunikasi dan Informasi (Kominfo). Responden yang dipilih dalam penelitian ini mewakili kabupaten atau kota adalah yang berkedudukan di empat perangkat daerah seperti tersebut di atas. Responden tersebut dapat terdiri dari Kepala Dinas atau Badan, Kepala Bidang, Kepala Sub Bidang, dan Staf. Kepala Dinas atau Badan bertanggung jawab kepada
Kepala Daerah melalui Sekretaris Daerah. Kepala Dinas atau Badan merupakan pejabat yang berfungsi sebagai penanggung jawab anggaran (PA). Penanggung jawab Anggaran memiliki tugas, diantaranya adalah penyusunan perencanaan dan penganggaran Dinas atau Badan, melakukan tindakan yang mengakibatkan pengeluaran atas beban anggaran belanja, melaksanakan anggaran Dinas atau Badan yang dipimpinnya, mengadakan ikatan atau perjanjian kerjasama dengan pihak lain dalam batas anggaran yang telah ditetapkan. Kepala Dinas atau Badan dapat melimpahkan sebagian kewenangannya kepada Kepala Bidang yang berfungsi sebagai kuasa pengguna anggaran (KPA). Kepala Sub Bidang adalah pejabat yang bertugas membantu Kepala Bidang untuk melaksanakan kegiatan terkait kewenangan bidangnya (RI, 2019). Staf dalam penelitian ini adalah pegawai yang bertugas membantu pelaksanaan kegiatan rutin maupun kegiatan yang bersifat manajerial pada sub Bidang. Hanya staf yang ditetapkan oleh Kepala Dinas atau Badan saja yang dapat mengisi kuesioner dengan pertimbangan dinilai mampu menyampaikan persepsinya guna mewakili kabupaten atau kota. Para responden tersebut dinilai dapat mewakili kabupaten atau kota karena terlibat dalam aktivitas yang bersifat manajerial sehingga dinilai mampu untuk memberikan persepsinya mengenai investasi TI, kinerja organisasi, dan Organizational Transformation. Sehubungan dengan unit analisis adalah level kabupaten atau kota, maka data yang terkumpul dari seluruh responden setiap kabupaten atau kota akan dijumlahkan dan dijadikan dalam satu grup, yaitu kabupaten atau kota yang bersangkutan. Unit analisis level organisasi memerlukan data dari responden yang lebih banyak namun selanjutnya akan dijadikan satu untuk memperoleh gambaran yang lebih memadai (Hair et al., 2014).

\section{Analisis Data}

Analisis data penelitian ini menggunakan SEM-PLS karena dapat digunakan 
untuk jumlah sampel kecil dan dapat mengestimasi model yang kompleks (Hair Jr et al., 2017). Sedangkan pengolahan data menggunakan aplikasi software Warp PLS 6.0. Penelitian ini menggunakan model second-order construct dengan reflective first order dan reflective second order (Hair Jr et al., 2017). Hal ini menunjukkan bahwa baik indikator maupun variabel laten diukur secara reflektif. Indikator dari variabel sebagai komponen first order merefleksikan variabel laten atau konstruk sebagai komponen second order. Setiap indikator diukur dengan satu atau lebih pertanyaan. Masingmasing variabel laten diukur dengan menggunakan beberapa indikator.

Analisis model struktural adalah model yang menjelaskan hubungan antar variabel laten atau konstruk (Hair Jr et al., 2016). Analisis ini dilakukan dengan melakukan uji Model Fit dan Multikolinearitas. Pengujian model ini untuk memastikan bahwa model penelitian yang diajukan telah didukung data. Model penelitian akan dinilai fit jika nilai $p$ untuk APC dan AARS $<0,05$. Model mediasi dinyatakan memenuhi uji multikolinearitas jika AVIF <3,3.

Pengujian hipotesis dilakukan dengan analisis jalur untuk menentukan pengaruh dan hubungan antar variabel serta dapat mengidentifikasi efek mediasi. Mengacu pada Kenny (2014) dilakukan prosedur pengujian sebagai berikut:

1. Menguji pengaruh langsung (a) antara investasi TI (ITI) dan Organizational Transformation (OT).

2. Menguji pengaruh langsung (b) antara TO dan KO.

3. Menguji pengaruh langsung (c) antara ITI dan KO tanpa melibatkan variabel mediasi.

4. Menguji pengaruh langsung ( $\left.c^{\prime}\right)$ antara ITI dan KO dengan melibatkan variabel mediasi.

Berdasarkan hasil pengujian di atas maka dapat dilakukan pemeriksaan hasil sebagai berikut:

1. Apabila $\left(c^{\prime}\right)$ tidak signifikan serta koefisien $c^{\prime}=0$, maka mediasi yang terjadi disebut mediasi sempurna (complete mediation).

2. Apabila $\left(c^{\prime}\right)$ signifikan serta koefisien $\left(c^{\prime}\right)$ $<$ koefisien (c) maka mediasi yang terjadi disebut mediasi tidak sempurna (incomplete mediation).

3. Apabila ( $\left.c^{\prime}\right)$ signifikan serta koefisien $\left(c^{\prime}\right)$ hampir sama dengan (c) maka dapat dikatakan tidak terjadi mediasi.

Hasil pengujian mediasi dengan mengacu pada koefisien ( $\left.c^{\prime}\right)$ dapat dikonfirmasi dengan menggunakan metode Variance Accounted For (VAF) agar lebih informatif. VAF dihitung dengan membagi pengaruh tidak langsung dengan pengaruh total. Pengaruh tidak langsung diperoleh dari a $x$ $\mathrm{b}$, sedangkan pengaruh total adalah $\mathrm{c}$ (Kenny, 2014).

\section{Hasil Dan Pembahasan Pilot Test}

Berdasarkan hasil loading-factor yang berkisar antara 0,741-1,000 atau >0,70 dan $p$ value $<0,001$ atau $<0,05$ (Hair et al., 2014), menunjukkan bahwa semua item pertanyaan dinyatakan memenuhi validitas konvergen atau dapat dijelaskan oleh indikator yang merefleksikannya. Hasil uji validitas diskriminan terpenuhi karena semua indikator memiliki loading (akar kuadrat AVE) lebih besar ke indikator itu sendiri daripada ke indikator yang lain. Hasil uji reliabilitas pilot test menunjukkan nilai composite reliability $>0,90$ dan croncbach's alpha $>0,80$, serta nilai AVE >0,70. Hasil tersebut menunjukkan bahwa item-item pertanyaan dapat mengukur indikator secara konsisten (Hair et al., 2014).

\section{Data dan Karakteristik Sampel Penelitian}

Sampel penelitian ini adalah $38 \mathrm{kabu}-$ paten atau kota dan masing-masing diberi 16 kuesioner atau 4 kuesioner per OPD. Total kuesioner yang disebar seharusnya berjumlah 608 kuesioner. Terdapat daerah yang mengembalikan kuesioner lebih dari 16 dikarenakan mereka menggandakan sendiri sehingga jumlah kuesioner yang disebar menjadi 613. Jumlah kuesioner yang kembali 
adalah sebanyak $538(87,76 \%)$ kuesioner dengan rincian 29 (5\%) kuesioner tidak diisi dengan lengkap dan 509 (83,03\%) kuesioner yang dapat diolah.

Semua kabupaten atau kota sampel penelitian telah menggunakan TI baik sebagai ICT maupun e-government. Saat mulai implementasi TI secara integrasi bervariasi mulai dari tahun 2003 bahkan ada yang baru direncanakan tahun 2019. Bila ditinjau dari besaran APBD, terdapat variasi mulai dari Rp.872.168.550.095,- hingga Rp.8.128.207. 032. $782,-$.

Jumlah responden laki-laki $(65,03 \%)$ lebih banyak dibanding responden perempuan $(34,97 \%)$. Ditinjau dari pendidikan, jumlah terbanyak adalah pendidikan S2 $(53,44 \%)$ dan S1 $(44,01 \%)$, sedangkan yang paling sedikit adalah S3 $(0,20 \%)$. Usia responden terbanyak berkisar antara 36-40 tahun $(24,56 \%)$ diikuti usia antara 41-45 tahun $(23,18 \%)$. Jabatan responden terbanyak adalah Kepala sub Bidang (304 responden) diikuti Kepala Bidang (159 responden) dan Kepala OPD (29 responden) sesuai dengan struktur organisasi yang ada. Partisipasi responden berdasar jabatan menunjukkan semakin tinggi jabatannya jumlah responden semakin kecil. Hal tersebut tidak menjadi masalah karena penentuan kriteria responden telah disampaikan pada saat pendistribusian kuesioner kepada Kepala OPD yang bersangkutan. Kepala OPD (sebagai penanggung jawab anggaran), selanjutnya membuat disposisi mengenai personal di bawahnya atau dirinya sendiri (sebagai PA) yang diminta mengisi kuesioner. Personel di bawah Kepala OPD terdiri atas Kepala Bidang (sebagai KPA), Kepala Sub Bidang, dan staf. Personel tersebut memiliki pengalaman dan pengetahuan yang memadai mengenai pemerintah daerah karena tugas pokok dan fungsinya terkait dengan aktivitas manajerial. Kepala OPD dalam membuat disposisi telah mempertimbangkan baik dari sisi jabatan, pengalaman, dan pengetahuan calon responden yang dinilai memiliki kapabilitas mewakili kabupaten atau kota untuk mengisi kuesi- oner. Kapabilitas personel terkait dengan penelitian ini adalah kemampuan memberikan persepsi mengenai investasi TI, organizational transformation, dan kinerja organisasi pada pemerintah daerah yang bersangkutan. Setiap responden dianggap memiliki tingkat pemahaman yang hampir sama secara memadai mengenai pertanyaan yang diajukan sehingga dapat memberi jawaban yang menggambarkan kondisi sebenarnya.

Dengan demikian, sedikitnya jumlah kepala OPD yang menjadi responden yang berkisar antara 0-3 orang, Kabid berkisar 1-9 orang atau bahkan ada yang hanya 1 atau 2 saja di setiap kabupaten atau kota tidak menjadi masalah. Masa kerja responden berdasar jumlah terbanyak secara berurutan masingmasing berkisar antara $11-15$ tahun $(25,74 \%)$, $\leq 10$ tahun $(19,65 \%), 16-20$ tahun $(19,06 \%)$, 21-25 tahun $(17,49 \%), 26-30$ tahun $(11,98 \%)$, dan $\geq 31$ tahun $(6,09 \%)$. Lama menjabat pada jabatan terakhir adalah $\leq 2$ tahun $(50,10 \%)$ dan yang paling sedikit adalah menduduki jabatan $>8$ tahun $(8,06 \%)$.

Berdasarkan statistik deskriptif, setiap indikator memiliki deviasi standar (SD) $<1$ dan nilainya dibawah mean (>4) menunjukkan bahwa jawaban responden atas setiap indikator kurang bervariasi. Hal ini menunjukkan konsistensi jawaban responden.

Investasi TI direfleksikan oleh beberapa indikator yang dapat dijelaskan sebagai berikut:

1. Kepemilikan Perangkat Keras (KPK)

Berdasarkan angka statistik, jawaban responden tentang KPK dari 38 kabupaten atau kota berkisar antara 4,519-6,271 dengan mode 5,083 < mean 5,378. Jawaban tersebut menunjukkan bahwa hampir semua kabupaten atau kota telah melakukan investasi komputer dan perangkat keras pendukungnya karena rata-rata jawaban $>5$ atau mendekati 7. Mode < mean mengindikasikan bahwa KPK sebagian kabupaten atau kota belum memadai.

2. Kapabilitas Aplikasi Perangkat Lunak (KAPS)

Jawaban responden tentang KAPS dari 38 
Kabupaten atau kota berkisar antara 3,894-6,200 dengan mode 4,575 < mean 5,091 . Kondisi tersebut menggambarkan bahwa pemahaman SDM pengguna TI, intensitas penggunaan software untuk keperluan internal dan eksternal, kapabilitas internet, serta updating keterampi- lan bidang TI kabupatenataukota di Jawa Timur tidak merata karena rentang jawaban minimum dan maksimum cukup besar, yaitu 2,306. Mode < mean mengindikasikan bahwa terdapat kecenderungan masih banyak kabupatenataukota yang KAPS belum memadai.

Tabel 2

Statistik Deskriptif

\begin{tabular}{lcrrrrc}
\hline \hline & Min & Max & Mean & Mode & Median & SD \\
\hline KPK & 4,519 & 6,271 & 5,378 & 5,083 & 5,344 & 0,418 \\
KAPS & 3,894 & 6,200 & 5,091 & 4,575 & 5,046 & 0,443 \\
JS & 3,484 & 6,305 & 4,956 & 3,484 & 4,995 & 0,581 \\
FTI & 3,569 & 6,427 & 4,936 & 5,073 & 4,976 & 0,594 \\
EOP & 4,625 & 6,500 & 5,389 & 5,375 & 5,375 & 0,368 \\
KJW & 4,507 & 6,250 & 5,436 & 5,859 & 5,357 & 0,403 \\
KPEK & 4,528 & 6,375 & 5,435 & 5,188 & 5,431 & 0,405 \\
KPAG & 4,556 & 6,438 & 5,638 & 5,625 & 5,646 & 0,406 \\
JMAK & 4,556 & 6,250 & 5,340 & 5,375 & 5,335 & 0,384 \\
KMTS & 4,583 & 6,313 & 5,320 & 4,875 & 5,271 & 0,360 \\
PSTG & 2,469 & 5,344 & 4,133 & 3,625 & 4,094 & 0,609 \\
PSTR & 3,313 & 5,594 & 4,214 & 3,750 & 4,177 & 0,478 \\
PDK & 4,146 & 5,719 & 4,892 & 5,391 & 4,901 & 0,390 \\
UP & 27,494 & 29,726 & 28,33 & 27,494 & 28,371 & 0,486 \\
\hline
\end{tabular}

Sumber: data penelitian, diolah

3. Jenis Software Berbasis Teknologi Internet Berdasar Fungsi (JS)

Mengacu angka statistik deskriptif menunjukkan jawaban responden tentang JS dari 38 kabupaten atau kota berkisar antara 3,484-6,305 dengan mode 3,484 < mean 4,956. Jawaban tersebut mengindikasi belum meratanya kepemilikan aplikasi software berdasarkan fungsi yang meliputi e-planning, e-budgeting, e-procurement, software manajemen aset, software akuntansi, e-service, e-monev, dan e-reporting yang dibutuhkan pemerintah kabupaten atau kota. Mode < mean diartikan bahwa masih lebih banyak kabupaten atau kota yang belum memiliki aplikasi software berdasarkan fungsi secara lengkap.

4. Fitur TI (FTI)

Berdasarkan angka statistik deskriptif, jawaban responden dari 38 kabupaten atau kota tentang fitur TI berkisar antara 3,569-6,427 dengan mode 5,073 > mean 4,936. Jawaban tersebut menunjukkan bahwa kemudahan akses dan penggunaan software, integrasi software, penggunan berbagai devices untuk akses software, keamanan aplikasi software, serta dinamisnya website antar kabupaten kota sangat bervariasi. Mode > mean mengindikasikan bahwa sebagian besar kabupaten atau kota memiliki fitur TI yang memadai.

Kinerja organisasi direfleksikan oleh beberapa indikator yang dapat dijelaskan sebagai berikut:

1. Efisiensi Operasional (EOP)

Angka statistik menunjukkan jawaban responden dari 38 kabupaten atau kota mengenai efisiensi biaya administrasi perkantoran dan pengadaan barang atau 
jasa berkisar antara 4,625-6,500 dengan mode 5,375 < mean 5,389. Jawaban tersebut menunjukkan bahwa hampir semua kabupaten atau kota telah dinilai mampu melaksanakan operasionalnya dengan tingkat efisiensi yang bervariasi. Mode < mean dengan perbedaan kecil, mengindikasikan bahwa sebagian kecil kabupaten atau kota yang telah mencapai efisiensi yang tinggi.

2. Ketaatan pada Jadwal (KJW)

Jawaban responden dari 38 kabupaten atau kota mengenai ketaatan jadwal berkisar antara 4,507-6,250 dengan mode $5,859>$ mean 5,436. Jawaban tersebut menunjukkan bahwa hampir semua kabupaten atau kota cenderung telah melakukan secara tepat waktu untuk perencanaan, penganggaran, pelaksanaan kegiatan, dan laporan pertanggung jawaban. Mode > mean mengindikasi lebih banyak kabupaten atau kota yang taat pada jadwal di atas rata-rata.

3. Kecepatan Penyelesaian Pekerjaan (KPEK)

Berdasarkan angka statistik deskriptif, jawaban responden tentang KPEK dari 38 kabupaten atau kota berkisar antara 4,528-6,375 dengan mode 5,188 < mean 5,435 . Jawaban tersebut menunjukkan bahwa hampir semua kabupaten atau kota telah cenderung melakukan pekerjaan dengan cepat meskipun tingkat kecepatan bervariasi. Mode < mean mengindikasi bahwa masih lebih banyak kabupaten atau kota yang kecepatan melaksanakan pekerjaannya di bawah rata-rata.

4. Kepatuhan pada Anggaran (KPAG) Jawaban responden tentang kepatuhan pada anggaran dari 38 kabupaten atau kota berkisar antara 4,556-6,438 dengan mode 5,625 < mean 5,638. Jawaban tersebut menunjukkan bahwa rata-rata kabupaten atau kota cenderung melakukan belanja sesuai pruntukannya. Sebagian besar kabupaten atau kota dalam hal kepatuhan anggaran berada pada level yang hampir sama mengingat selisih mode dan mean hanya 0,013. Hanya sebagian kecil saja yang memiliki tingkat kesesuaian yang tinggi untuk anggaran belanja dan peruntukannya.

5. Jumlah Aktivitas (JMAK)

Berdasarkan angka statistik, jawaban responden tentang JMAK dari 38 kabupaten atau kota berkisar antara 4,5566,250 dengan mode 5,375 > mean 5,340. Jawaban tersebut menunjukkan bahwa terdapat kecenderungan terdapat kesesuaian antara kapasitas dan jumlah aktivitas kabupaten atau kota karena ratarata dan mode $>5$.

6. Kemampuan Memenuhi Tujuan dan Sasaran (KMTS)

Deskriptif statistik menunjukkan jawaban responden dari 38 kabupaten atau kota tentang kemampuan memenuhi tujuan dan sasaran berkisar antara 4,583-6,313 dengan mode 4,875 < mean 5,320. Jawaban tersebut menggambarkan masih terdapat lebih banyak kabupaten atau kota yang memiliki kecenderungan mencapai tujuan dan sasaran secara efektif serta memberi kepuasan layanan masyarakat di bawah rata-rata. Hanya sedikit kabupaten kota yang telah mampu mencapai tujuan dan sasaran secara efektif serta memuaskan layanan kepada masyarakat.

Organizational Transformation direfleksik oleh beberapa indikator yang dapat dijelaskan sebagai berikut:

1. Perubahan Strategi (PSTG)

Berdasarkan angka statistik deskriptif, jawaban responden tentang PSTG dari 38 kabupaten atau kota berkisar antara 2,469-5,344 dengan mode 3,625 < mean 4,133. Jawaban tersebut menggambarkan bahwa masih terdapat kabupaten atau kota yang cenderung tidak mengalami perubahan konten rumusan dan proses penyusunan strategi.

2. Perubahan Struktur (PSTR)

Angka statistik deskriptif menunjukkan jawaban responden tentang PSTR dari 38 kabupaten atau kota berkisar antara 3,313-5,594 dengan mode 3,750 < mean 4,214 . Jawaban tersebut menggambarkan 
bahwa sebagian besar kabupaten atau kota cenderung tidak mengalami perubahan bentuk organisasi serta cara dan prosedur kerja.

3. Perubahan Distribusi Kekuasaan (PDK)

Berdasarkan angka statistik deskriptif, jawaban responden tentang PDK dari 38 kabupatenataukota berkisar antara 4,1465,719 dengan mode 5,391 < mean 4,892. Jawaban tersebut mengindikasi bahwa hampir semua kabupatenataukota telah memiliki kecenderungan yang belum tinggi adanya perubahan distribusi kekuasaan. Perubahan distribusi kekuasaan tersebut meliputi adanya perubahan pendelegasian wewenang dan tanggungjawab serta seringnya perputaran jawaban.

\section{Analisis Model Pengukuran Reflektif Analisis First-Order}

Berdasarkan hasil uji validitas konvergen first order menunjukan bahwa semua item pernyataan yang diajukan dapat merefleksi indikator. Setiap item pernyataan memiliki nilai loading factor $>0,7$ kecuali KPK2, JS1, PDK1, dan PDK2 masing-masing adalah 0,$639 ; 0,631 ; 0,526 ; 0,638$ atau $0,4<$ nilai loading factor $<0,7$, serta $p$ value $<0,001$. Keempat item pernyataan tersebut dipertimbangkan untuk dipertahankan karena merupakan kuesioner yang baru dikembangkan.

Berdasarkan hasil uji validitas diskriminan first order, setiap indikator dinilai valid karena memiliki nilai cross loading lebih tinggi ke indikator itu sendiri dibanding ke indikator lainnya. Hasil tersebut menunjukkan bahwa setiap indikator yang digunakan dalam penelitian ini menunjukkan validitas diskriminan yang baik atau bersifat unik.

Berdasarkan Composite Reliability (CR) dan Cronbach's Alpha (CA), setiap indikator dinyatakan reliabel karena masing-masing nilainya $C R>0,70$ dan $C A>0,60$ sesuai yang disyaratkan (Hair Jr et al., 2016). Hasil tersebut menunjukkan bahwa item-item pernyataan dapat mengukur indikator secara konsisten.
Tabel 3

Hasil Uji Reliabilitas First Order

\begin{tabular}{lccc}
\hline Indikator & $\begin{array}{c}\text { Composite } \\
\text { Reliability }\end{array}$ & $\begin{array}{c}\text { Cronbach's } \\
\text { Alpha }\end{array}$ & $\begin{array}{c}\text { Avrg. } \\
\text { Var. } \\
\text { Extrac }\end{array}$ \\
\hline KPK & 0,910 & 0,881 & 0,631 \\
KAPS & 0,909 & 0,875 & 0,669 \\
JS & 0,920 & 0,900 & 0,594 \\
FTI & 0,948 & 0,934 & 0,753 \\
EOP & 0,962 & 0,920 & 0,926 \\
KJW & 0,970 & 0,958 & 0,889 \\
KPEK & 1,000 & 1,000 & 1,000 \\
KPAG & 1,000 & 1,000 & 1,000 \\
JMAK & 1,000 & 1,000 & 1,000 \\
KMTS & 0,876 & 0,717 & 0,779 \\
PSTG & 0,971 & 0,941 & 0,944 \\
PSTR & 0,876 & 0,716 & 0,779 \\
PDK & 0,797 & 0,666 & 0,503 \\
\hline
\end{tabular}

Sumber: data penelitian, diolah

\section{Analisis Second-Order}

Hasil uji validitas konvergen menunjukkan semua indikator dinilai valid karena memiliki loading factor $<0,7$, kecuali PDK dengan loading factor sebesar 0,465 atau >0,4. Semua indikator memiliki $p$ value $<0,001$.

Tabel 4

Hasil Uji Validitas Konvergen Second-Order

\begin{tabular}{ccc}
\hline \hline Indikator & $\begin{array}{c}\text { Loading } \\
\text { Factor }\end{array}$ & P-Value \\
\hline KPK & 0,861 & $<0,001$ \\
KAPS & 0,895 & $<0,001$ \\
JS & 0,816 & $<0,001$ \\
FTI & 0,901 & $<0,001$ \\
EOP & 0,849 & $<0,001$ \\
KJW & 0,933 & $<0,001$ \\
KPEK & 0,929 & $<0,001$ \\
KPAG & 0,935 & $<0,001$ \\
JMAK & 0,942 & $<0,001$ \\
KMTS & 0,881 & $<0,001$ \\
PSTG & 0,866 & $<0,001$ \\
PSTR & 0,868 & $<0,001$ \\
PDK & 0,465 & $<0,001$ \\
\hline
\end{tabular}

Sumber: data penelitian, diolah

Berdasarkan hasil uji validitas diskriminan second order, setiap variabel penelitian ini dinyatakan valid karena 
memiliki cross loading yang lebih rendah ke variabel lainnya dibanding ke variabel itu sendiri. Setiap variabel laten yang digunakan dinilai memiliki sifat unik.

\section{Tabel 5}

Hasil Uji Validitas Diskriminan Second Order

\begin{tabular}{ccc}
\hline \hline Variabel & $\begin{array}{c}\text { Cross } \\
\text { Loading }\end{array}$ & Hasil \\
\hline ITI & 0,869 & Valid \\
KO & 0,912 & Valid \\
OT & 0,757 & Valid \\
\hline
\end{tabular}

Sumber: data penelitian, diolah

Berdasarkan hasil Composite Reliability dan Cronbach's Alpha, setiap variabel dinyatakan reliabel karena masing-masing nilainya memenuhi persyaratan, yaitu $\mathrm{CR}>$ 0,70 dan $\mathrm{CA}>0,60$. Hasil tersebut menunjukkan bahwa indikator dapat mengukur variabel laten secara konsisten.

Tabel 6

Hasil Uji Reliabilitas Second Order

\begin{tabular}{cccc}
\hline \hline Variabel & $\begin{array}{c}\text { Composite } \\
\text { Reliability }\end{array}$ & $\begin{array}{c}\text { Cronbach's } \\
\text { Alpha }\end{array}$ & $\begin{array}{c}\text { Avrg. } \\
\text { Var. } \\
\text { Extrac }\end{array}$ \\
\hline ITI & 0,925 & 0,891 & 0,755 \\
KO & 0,967 & 0,959 & 0,832 \\
OT & 0,791 & 0,601 & 0,573 \\
\hline
\end{tabular}

Sumber: data penelitian, diolah

\section{Analisis Model Struktural}

Pengujian Model Fit dan Multikolinearitas menghasilkan $p$ value untuk APC dan AARS $<0,05$, serta AVIF $<3,3$. Hasil tersebut menunjukkan bahwa model dalam penelitian ini didukung data. Model mediasi dinilai memenuhi uji multikolinearitas karena AVIF $<3,3$.

Tabel 7

Pengujian Model Fit dan Multikolinearitas

\begin{tabular}{cccc}
\hline \hline Model & APC & AARS & AVIF \\
\hline ITI-OT-KO & $0,277^{* *}$ & $0,317^{* *}$ & 1,352
\end{tabular}

Sumber: data penelitian, diolah ${ }^{* *} \mathrm{p}<0,05$
APC: Average Path Coefficient

AARS: Average Adjusted R-Squared

AVIF: Average block Variant Inflation Factor

\section{Uji Hipotesis}

Uji hipotesis dapat dilihat dari hasil pengujian pengaruh langsung dan tidak langsung.

\section{Tabel 8 \\ Hasil PLS}

(path coefficient (t statistik), p-value, \& $\mathbf{R}^{2}$ )

\begin{tabular}{|c|c|c|}
\hline \multicolumn{3}{|c|}{ Panel A: Pengaruh Langsung } \\
\hline \multirow[t]{2}{*}{ Variabel } & \multicolumn{2}{|c|}{ Ke Jalur } \\
\hline & \multicolumn{2}{|c|}{$\mathrm{KO}$} \\
\hline ITI & \multicolumn{2}{|c|}{$0,805(7,072)^{* * *}$} \\
\hline $\mathrm{R}^{2}$ & \multicolumn{2}{|c|}{0,647} \\
\hline \multirow[t]{2}{*}{ Variabel } & \multicolumn{2}{|c|}{ Ke Jalur } \\
\hline & \multicolumn{2}{|c|}{ OT } \\
\hline ITI & \multicolumn{2}{|c|}{$0,253(1,745)^{* *}$} \\
\hline $\mathrm{R}^{2}$ & \multicolumn{2}{|c|}{0,064} \\
\hline \multirow[t]{2}{*}{ Variabel } & \multicolumn{2}{|c|}{ Ke Jalur } \\
\hline & \multicolumn{2}{|c|}{$\mathrm{KO}$} \\
\hline OT & \multicolumn{2}{|c|}{$0,241(1,652)^{*}$} \\
\hline $\mathrm{R}^{2}$ & \multicolumn{2}{|c|}{0,058} \\
\hline \multicolumn{3}{|c|}{ PANEL B: Pengaruh Tidak Langsung } \\
\hline \multirow[t]{3}{*}{ Variabel } & \multicolumn{2}{|c|}{ Ke Jalur } \\
\hline & OT & $\mathrm{KO}$ \\
\hline & $\begin{array}{c}0,253 \\
(1,745)^{* *}\end{array}$ & $0,772(6,691)^{\star * *}$ \\
\hline OT & & $-0,046(-0,291)$ \\
\hline UP & & $0,083(0,235)$ \\
\hline $\mathrm{R}^{2}$ & 0,064 & 0,628 \\
\hline
\end{tabular}

Sumber: data penelitian, diolah

${ }^{* * *} \mathrm{p}<0,01{ }^{* *} \mathrm{p}<0,05{ }^{*} \mathrm{p}<0,10$

\section{Uji Pengaruh Langsung}

Investasi Teknologi Informasi (ITI) berpengaruh positif signifikan terhadap Kinerja Organisasi pada pemerintah daerah dengan path coefficient $=0,805, p$ value $<0,01, \mathrm{R}^{2}=$ 0,647 . Hal ini menunjukkan bahwa semakin besar investasi TI maka semakin baik pula 
kinerja organisasi pada pemerintah daerah. Investasi Teknologi Informasi (ITI) berpengaruh positif signifikan terhadap Organizational Transformation (OT) pada pemerintah daerah dengan path coefficient $=0,253$, $p$-value $=0,04$ atau $<0,05, R^{2}=0,064$. Hal ini menunjukkan bahwa semakin besar investasi TI maka akan berdampak adanya Organizational Transformation pada pemerintah daerah.

Organizational Transformation (OT) berpengaruh positif signifikan terhadap Kinerja Organisasi $(\mathrm{KO})$ pada pemerintah daerah dengan path coefficient $=0,241$, $p$-value $=0,05$ $<0,10, \mathrm{R}^{2}=0,058$. Hal ini menunjukkan bahwa semakin banyak Organizational Transformation yang dilakukan maka kinerja organisasi pada pemerintah daerah semakin baik.

\section{Uji Pengaruh Tidak Langsung}

Hasil pengujian pengaruh investasi TI terhadap kinerja organisasi dengan memasukkan organizational transformation sebagai variabel mediasi, path coefficient $\left(\mathrm{c}^{\prime}\right)=$ $0,772, p$-value $<0,01, R^{2}=0,628$. Hasil tersebut menunjukkan path coefficient ( $\left.c^{\prime}\right)$ lebih rendah dari path coefficient (c) pengaruh total atau pengaruh sebelum memasukkan variabel mediasi, berarti terdapat mediasi parsial secara positif. Hasil ini dapat dikonfirmasi dengan menggunakan metode VAF diperoleh hasil sebesar $1,5 \%$ atau $\mathrm{VAF} \leq 20 \%$ menunjukkan mediasi yang sangat lemah. Mediasi parsial ini menunjukkan bahwa organizational transformation bukan satusatunya variabel mediasi pengaruh investasi TI terhadap kinerja organisasi pada pemerintah daerah. Dengan demikian, $\mathrm{H}_{1}$ yang menyatakan organizational transformation memediasi secara positif pengaruh investasi TI terhadap kinerja organisasi pada pemerintah daerah, didukung.

\section{Pembahasan \\ Investasi Teknologi Informasi dan Kinerja Organisasi}

Berdasarkan hasil uji statistik terbukti bahwa terdapat pengaruh positif signifikan antara investasi TI dan kinerja organisasi pada pemerintah daerah. Semua kabupaten atau kota di Jawa Timur telah melakukan investasi TI meskipun besarannya belum merata, hal ini tercermin dari jumlah aplikasi software yang digunakan dan integrasi sistem yang dibangun. Investasi TI yang dilakukan masih banyak untuk perangkat keras, sedangkan terkait kapabilitas perangkat lunak, aplikasi software pendukung aktivitas pemerintah daerah, dan kualitas fitur TI masih kurang. Kondisi ini mempengaruhi kinerja (work performance) organisasi pada pemerintah daerah.

Hasil uji statistik ini mendukung hasil penelitian Maal-Gharaibeh dan Malkawi (2013) yang menyatakan bahwa investai TI selain hardware dan software pada organisasi pemerintah, yang sangat penting untuk meningkatkan kinerja organisasi pemerintah adalah SDM dan jaringan. Bukti empiris ini juga mendukung empat karakteristik process theory (Markus dan Robey, 1988; Mohr, 1982; Soh dan Markus, 1995).

Karakteristik pertama, yaitu setelah dilakukan investasi TI ditemukan kejadian yang berbeda seperti efisiensi operasional, ketaatan pada jadwal, kecepatan penyelesaian pekerjaan, kepatuhan pada anggaran, jumlah aktivitas yang dapat dilakukan, dan kemampuan memenuhi tujuan dan sasaran. Karakteristik kedua, ditinjau secara logis bahwa peningkatan kinerja organisasi pada pemerintah daerah dapat terjadi karena telah terpenuhinya kebutuhan TI yang memadai. Karakteristik ketiga, outcome berupa peningkatan kinerja organisasi pada pemerintah daerah sangat mungkin tidak tercapai meskipun telah dilakukan investasi TI. Hasil penelitian ini menunjukkan bahwa investasi TI telah efektif karena telah mampu meningkatkan kinerja organisasi. Karakteristik keempat, yaitu urutan waktu terjadinya peningkatan kinerja pada pemerintah daerah terjadi setelah dilakukan investasi TI.

\section{Investasi Teknologi Informasi, Kinerja Organisasi, dan Organizational Trans- formation}


Hasil pengujian tidak langsung dari model mediasi apabila ditinjau dari path coefficient ( $c^{\prime}$ ) menunjukkan bahwa transformasi organisasional memediasi pengaruh investasi TI terhadap kinerja organisasi pada pemerintah daerah. Pengaruh investasi TI terhadap transformasi organisasional dalam model mediasi tersebut masih menunjukkan pengaruh positif signifikan. Model mediasi ini dapat dikategorikan sebagai proximal mediator karena path coefficient pengaruh investasi TI terhadap transformasi organisasional $(\mathrm{a}=0,253)$ lebih besar dibanding path coefficient pengaruh transformasi organisasional terhadap kinerja organisasi $(b=$ 0,046).

Hasil pengujian menunjukkan adanya inkonsistensi mediasi, yaitu path coefficient pengaruh langsung setelah memasukkan variabel mediasi $\left(c^{\prime}\right)$ adalah positif sedangkan path coefficient pengaruh tidak langsung (ab) adalah negatif, dengan (a) signifikan dan (b) tidak signifikan. Perbedaan arah kedua path coefficient tersebut tetap mengindikasi bahwa transformasi organisasional memediasi secara parsial pengaruh investasi TI terhadap kinerja organisasi pada pemerintah daerah (Kenny, 2014). Pengaruh negatif tidak signifikan (b) tersebut dapat terjadi karena responden berpersepsi atas transformasi organisasional berdasarkan kondisi sebelumnya hingga saat pengisian kuesioner saja. Responden tidak mempertimbangkan realisasi pemberlakuan peraturan baru yang mendasari transformasi organisasional beberapa saat mendatang. Pemerintah daerah tidak dapat secara langsung dapat melakukan transformasi organisasional pada saat terdapat peraturan baru yang ditetapkan oleh pemerintah, misalnya Peraturan Pemerintah Nomor 18 tahun 2016 tentang Perangkat Daerah, Peraturan Pemerintah Nomor 12 tahun 2019 tentang Pengelolaan Keuangan Daerah. Peraturan dari pemerintah pusat tersebut tidak dapat mengikat pemerintah daerah secara langsung, artinya pemerintah daerah harus mengadopsi sebagai peraturan daerah untuk menggantikan peraturan daerah yang berlaku sebelumnya. Proses penyusunan peraturan daerah baru tersebut membutuhkan waktu yang cukup lama hingga sampai diputuskan oleh DPRD sebagai peraturan daerah. Durasi waktu yang dibutuhkan setiap daerah terkait penyusunan peraturan daerah dan tingkat respon atas peraturan baru tidak sama.

Investasi TI seharusnya dapat mendorong terjadinya Organizational Transformation, namun terdapat kendala dalam penerapannya, yaitu masalah teknis dan administrasi (Ribeiro et al., 2018). Terdapat beberapa kunci sukses penerapan Organizational Transformation yang harus dipertimbangkan, yaitu dukungan manajemen, kepemimpinan, komitmen untuk bertransformasi, pendekatan transformasi yang tepat, uji coba, pelatihan, menyatukan anggota organisasi, komunikasi dan transparansi, pola pikir dan keselarasan, otonomi tim, serta persyaratan manajemen (Dikert et al., 2016) yang akhirnya dapat membantu pemerintah daerah meningkatkan kinerja organisasinya. Transformasi Organisasional dalam penelitian ini memiliki peran mediasi parsial dalam hubungan antara investasi TI dan kinerja organisasi meskipun sangat lemah. Setelah adanya Transformasi Organisasional nampak jelas mengubah koefisien hubungan langsung antara investasi TI dan kinerja organisasi menjadi lebih kecil dibandingkan sebelum adanya peran variabel mediasi meskipun selisihnya hanya 0,03 saja. Hal ini berarti Transformasi Organisasional dinilai mampu mengubah dampak hubungan variabel dependen ke independen secara parsial meskipun kecil (Fritz et al., 2016). Bukti empiris ini mendukung hasil penelitian Nwankpa dan Roumani (2016) bahwa TI mendorong dilakukannya Transformasi Organisasional guna meningkatkan kinerja organisasi. Selain itu juga mendukung Ebrahimi et al. (2016) yang menyatakan bahwa investasi TI sebagai inovasi organisasi yang diikuti dengan Transformasi Organisasional berdampak pada kelincahan organisasi dalam beraktivitas. Kedua hasil tersebut menunjukkan bahwa Transformasi 
Organisasional sangat diperlukan baik di perusahaan komersial maupun sektor publik setelah dilakukannya investasi TI agar dapat meningkatkan kinerja organisasi.

Proses peran Transformasi Organisasional dalam hubungan investasi TI dengan kinerja organisasi pada pemerintah daerah dapat dikategorikan sebagai bagian dari proses model perubahan teleology (Van de Ven dan Poole, 1995). Ditinjau dari unit perubahan proses ini hanya melibatkan satu entitas saja yaitu pemerintah daerah itu sendiri. Model teleology berasumsi bahwa organisasi menginginkan perubahan saat terdapat kesempatan, adanya masalah atau ancaman yang harus dihadapi dan diselesaikan (Van de Ven dan Sun, 2011). Pemerintah daerah memiliki kesempatan untuk melakukan perubahan menuju implementasi e-government didukung oleh peraturan dan perundangan berlaku. Penerapan e-government ini untuk menjawab tantangan mampu memanfaatkan TI di era digital secara efektif dan efisien. Kondisi tersebut mendorong pemerintah daerah merencanakan investasi TI sebagai awal proses perubahan. Pemerintah daerah perlu melakukan transformasi organisasional agar investasi TI tersebut dapat diimplementasikan. Transformasi Organisasional ini digunakan untuk memperbaiki kondisi organisasi, misalnya dengan adanya perubahan standard operational procedure, perubahan konten dan proses perencanaan strategi, perubahan pendelegasian kewenangan dan perubahan distribusi kekuasaan. Pemerintah daerah masih memiliki kecenderungan yang rendah untuk melakukan transformasi organisasional tersebut. Hal ini menunjukkan sebagian besar pemerintah daerah belum banyak melakukan transformasi organisasional yang menjadi syarat implementasi TI. Penyebab utama sedikitnya perubahan ini adalah adanya: 1) hal normatif yang melekat pada institusi, misalnya peraturan perundangan yang berlaku terkait organisasi; 2) kecepatan perubahan antar Organisasi Perangkat Daerah berbeda satu sama lain; dan 3) dinamika internal organisasi bervariasi. Perubahan organisasi tersebut disertai dengan adanya kompleksitas kelembagaan (Hinings et al., 2018). Pemerintah daerah dalam melakukan transformasi organisasional tidak dapat secepat yang dilakukan oleh perusahaan komersial. Setiap perubahan yang dilakukan pemerintah daerah harus mengacu pada peraturan perundangan yang berlaku. Selain itu ada tenggang waktu antara dikeluarkannya peraturan perundangan baru dengan realisasi perubahan itu sendiri. Proses perubahan organisasi teleology ini membutuhkan konsensus untuk menerapkan perubahan tersebut. Transformasi organisasional yang dilakukan pemerintah daerah dapat memperbaiki kinerja organisasi, seperti yang diungkapkan oleh Plesner et al. (2018) antara lain efisiensi dan efektivitas birokrasi, serta peningkatan akuntabilitas profesionalitas penyelenggaraan pemerintah daerah. Pada penelitian ini transformasi organisasional sedikit berkontribusi pada peningkatan kinerja organisasi pada pemerintah daerah yang meliputi efisiensi operasional, ketaatan pada jadwal, kecepatan penyelesaian pekerjaan, kepatuhan pada anggaran, jumlah aktivitas, serta kemampuan memenuhi tujuan dan sasaran. Hal tersebut dapat dilihat dari menurunnya path coeficient yang kecil, namun demikian masih dinilai memiliki peran mediasi.

\section{SIMPULAN DAN SARAN}

Penelitian ini membuktikan bahwa organizational transformation memiliki peran yang lemah dalam memediasi parsial secara positif hubungan investasi TI dengan kinerja organisasi pada pemerintah daerah. Pemerintah daerah dinilai lambat dalam melakukan organizational transformation yang diperlukan untuk implementasi TI. Pelaksanaan organizational transformation tersebut membutuhkan acuan peraturan perundangan. Kecepatan investasi TI dan dukungan peraturan perundangan terhadap organizational transformation pada pemerintah daerah tidak seimbang. Organizational transformation yang terjadi lebih cenderung 
memenuhi ketentuan peraturan perundangan dibanding keperluan implementasi TI. Dengan demikian transformasi organisasional belum mampu berkontribusi pada peningkatan kinerja organisasi pemerintah daerah.

Penelitian ini memiliki keterbatasan, yaitu: 1) sifat sampel yang diperoleh dengan mengggunakan convenience sampling method memungkinkan membatasi generalisasi hasil penelitian; 2) data yang diperoleh dengan menggunakan metode survey memungkinkan adanya bias. Penelitian selanjutnya disarankan: 1) menggunakan random sampling method, yaitu dengan menggunakan responden secara random dari populasi umum untuk validitas hasil penelitian; 2) menggunakan ukuran variabel yang lebih obyektif, yaitu dari data publik yang tersedia.

Berdasarkan kesimpulan penelitian ini, pemerintah sebagai regulator harus lebih cepat dalam menyediakan peraturan perundangan yang mengakomodasi penerapan TI di pemerintah daerah. Pemerintah daerah harus kreatif dan responsif dalam melakukan transformasi organisasional terkait dengan implementasi TI, misal menambah poin tugas pokok dan fungsi selain yang telah diatur dalam peraturan perundangan

\section{DAFTAR PUSTAKA}

Alaaraj, H. dan F. W. Ibrahim. 2014. The Influence of E-government Practices on Good Governance from the Perspective of Public in Lebanon. Journal of Public Administration and Governance 4(3): 171185.

Alenezi, H., A. Tarhini, dan R. Masa'deh. 2015. Investigating the strategic relationship between information quality and e-government benefits: A literature review.

Aral, S. dan P. Weill. 2007. IT assets, organizational capabilities, and firm performance: How resource allocations and organizational differences explain performance variation. Organization science 18(5): 763-780.

Baker, J., J. Song, dan D. R. Jones. 2017. Closing the loop: Empirical evidence for a positive feedback model of IT business value creation. The Journal of Strategic Information Systems 26(2): 142-160.

Burton-Jones, A., E. R. McLean, dan E. Monod. 2015. Theoretical perspectives in IS research: from variance and process to conceptual latitude and conceptual fit. European Journal of Information Systems 24(6): 664-679.

Cha, K. J., T. Hwang, dan S. Gregor. 2015. An integrative model of IT-enabled organizational transformation: A multiple case study. Management Decision 53(8): 17551770.

Coombs, C. R. 2015. When planned ISatauIT project benefits are not realized: a study of inhibitors and facilitators to benefits realization. International Journal of Project Management 33(2): 363-379.

Cordella, A. dan N. Tempini. 2015. Egovernment and organizational change: Reappraising the role of ICT and bureaucracy in public service delivery. Government information quarterly 32(3): 279-286.

Criado, J. I., F. Rojas-Martín, dan J. R. GilGarcia. 2017. Enacting social media success in local public administrations: An empirical analysis of organizational, institutional, and contextual factors. International Journal of Public Sector Management 30(1): 31-47.

Dikert, K., M. Paasivaara, dan C. Lassenius. 2016. Challenges and success factors for large-scale agile transformations: A systematic literature review. Journal of Systems and Software 119: 87-108.

Ebrahimi, P., S. M. Moosavi, dan E. Chirani. 2016. Relationship between leadership styles and organizational performance by considering innovation in manufacturing companies of guilan province. Procedia-Social and Behavioral Sciences, 230: 351-358. 
Etikan, I., S. A. Musa, dan R. S. Alkassim. 2016. Comparison of convenience sampling and purposive sampling. American journal of theoretical and applied statistics 5(1): 1-4.

Fernandez, S. dan H. G. Rainey. 2017. Managing successful organizational change in the public sector Debating Public Administration, 7-26: Routledge.

Fritz, M. S., D. A. Kenny, dan D. P. MacKinnon. 2016. The combined effects of measurement error and omitting confounders in the single-mediator model. Multivariate Behavioral Research 51(5): 681-697.

Gao, P. 2015. Government in the catching-up of technology innovation: Case of administrative intervention in China. Technological Forecasting and Social Change 96: 4-14.

Gil-Garcia, J. R., N. Helbig, dan A. Ojo. 2014. Being smart: Emerging technologies and innovation in the public sector. Government information quarterly 31: I1I8.

Greve, C. 2015. Ideas in public management reform for the 2010s. Digitalization, value creation and involvement. Public organization review 15(1): 49-65.

Hair, J. F., W. C. Black, B. J. Babin, dan R. E. Anderson. 2014. Multivariate data analysis: Pearson new international edition. Essex: Pearson Education Limited.

Hair Jr, J. F., G. T. M. Hult, C. Ringle, dan M. Sarstedt. 2016. A primer on partial least squares structural equation modeling (PLSSEM): Sage publications.

Hair Jr, J. F., L. M. Matthews, R. L. Matthews, dan M. Sarstedt. 2017. PLS-SEM or CBSEM: updated guidelines on which method to use. International Journal of Multivariate Data Analysis 1(2): 107-123.

Hernes, T. 2014. A process theory of organization: OUP Oxford.

Hinings, B., T. Gegenhuber, dan R. Greenwood. 2018. Digital innovation and transformation: An institutional perspective. Information and Organization 28(1): 52-61.
Hossan, C. 2015. Applicability of Lewin's change management theory in Australian local government. International Journal of business and Management 10(6): 53.

Jacobsen, J., H. B. Fosse, dan A. Sorensen. 2017. IT-Intensive Machinery and Equipment, Organizational Change and Productivity Growth. Organizational Change and Productivity Growth (May 31, 2017).

Janowski, T. 2015. Digital government evolution: From transformation to contextualization. Government information quarterly 32(3): 221-236.

Jung, B. 2019. A Performance by New Technology Investment and Legal System Operation in Government Organization. Journal of Digital Convergence 17(6): 133-144.

Kenny, D. 2014. Mediation. 2014.

Khallaf, A., M. A. Omran, dan T. Zakaria, 2017. Explaining the inconsistent results of the impact of information technology investments on firm performance: A longitudinal analysis. Journal of Accounting \& Organizational Change, 13(3): 359-380.

Kobelsky, K., G. Larosiliere, dan E. Plummer. 2014. The impact of information technology on performance in the not-forprofit sector. International Journal of Accounting Information Systems 15(1): 4765.

Kuhlmann, S. 2010. Performance Measurement in European local governments: a comparative analysis of reform experiences in Great Britain, France, Sweden and Germany. International Review of Administrative Sciences 76(2): 331-345.

Laudon, K. C. dan J. P. Laudon. 2018. Management information systems: managing the digital firm (Fifteenth Edition Global Edition ed.): Pearson.

Lee, O. K. D. 2012. IT-enabled organizational transformations to achieve business agility. The Review of Business Information Systems (Online) 16(2): 43. 
Loebbecke, C. dan A. Picot. 2015. Reflections on societal and business model transformation arising from digitization and big data analytics: A research agenda. The Journal of Strategic Information Systems 24(3): 149-157.

Maal-Gharaibeh, S. dan N. M. Malkawi. 2013. The impact of management information systems on the performance of governmental organizations-study at Jordanian ministry of planning. International Journal of Business and Social Science 4(17).

Markus, M. L. dan D. Robey. 1988. Information technology and organizational change: causal structure in theory and research. Management science 34(5): 583598.

Mohr, L. B. 1982. Explaining organizational behavior (1): Jossey-Bass San Francisco, CA.

Nielsen, J. A. dan Pedersen, K. 2014. IT portfolio decision-making in local governments: Rationality, politics, intuition and coincidences. Government information quarterly 31(3): 411-420.

Nitzl, C., J. L. Roldan, dan G. Cepeda. 2016. Mediation analysis in partial least squares path modeling: Helping researchers discuss more sophisticated models. Industrial Management $\mathcal{E}$ Data Systems 116(9): 1849-1864.

Nograšek, J. dan M. Vintar. 2014. Egovernment and organisational transformation of government: Black box revisited? Government Information Quarterly 31(1): 108-118.

Nwankpa, J. K. dan Y. Roumani. 2016. IT capability and digital transformation: A firm performance perspective.

O'Rourke, H. P. dan D. P. MacKinnon. 2018. Reasons for testing mediation in the absence of an intervention effect: A research imperative in prevention and intervention research. Journal of studies on alcohol and drugs 79(2): 171-181.

Pang, M. S. 2014. IT governance and business value in the public sector organizations The role of elected representatives in IT governance and its impact on IT value in US state governments. Decision Support Systems 59: 274-285.

Peng, J., J. Quan, G. Zhang, dan A. J. Dubinsky. 2016. Mediation effect of business process and supply chain management capabilities on the impact of IT on firm performance: Evidence from Chinese firms. International Journal of Information Management 36(1): 89-96.

Plesner, U., L. Justesen, dan C. Glerup. 2018. The transformation of work in digitized public sector organizations. Journal of Organizational Change Management 31(5): 1176-1190.

Republik Indonesia. 2016. Peraturan Pemerintah Republik Indonesia Nomor 18 Tahun 2016 tentang Organisasi Perangkat Daerah. - 2018. Peraturan Presiden Nomor 95 Tahun 2018 tentang Sistem Pemerintahan Berbasis Elektronik.

- . 2019. Peraturan Pemerintah Republik Indonesia Nomor 12 Tahun 2019 tentang Pengelolaan Keuangan Daerah.

Ribeiro, M. M., E. H. Diniz, L. C. Oliveira, dan S. M. Faleiros. 2018. Information systems and intergovernmental relations in Brazilian social policies: a study on users' adaptations to the local context. RAUSP Management Journal 53(1): 86-97.

Romanelli, E. dan M. L. Tushman. 1994. Organizational transformation as punctuated equilibrium: An empirical test. Academy of Management Journal 37(5): 1141-1166.

Rowe, F., P. Besson, dan A. Hemon. 2017. Socio-technical inertia, dynamic capabilities and environmental uncertainty: Senior management views and implications for organizational transformation.

Sabherwal, R. dan A. Jeyaraj. 2015. Information Technology Impacts on Firm Performance: An Extension of Kohli and Devaraj (2003). MIS quarterly 39(4): 809836.

Sharma, P., M. Sarstedt, G. Shmueli, K. H. Kim, dan K. O. Thiele. 2019. PLS-based 
model selection: the role of alternative explanations in information systems research. Journal of the Association for Information Systems 20(4): 4.

Sivarajah, U., Z. Irani, dan V. Weerakkody. 2015. Evaluating the use and impact of Web 2.0 technologies in local government. Government information quarterly 32(4): 473-487.

Smith, H. A. dan J. McKeen. 1991. How does information technology affect business value-A reassessment and research propositions. Paper presented at the System Sciences, 1991. Proceedings of the Twenty-Fourth Annual Hawaii International Conference on.

Soh, C. dan M. L. Markus. 1995. How IT creates business value: a process theory synthesis. ICIS 1995 Proceedings, 4.

Teryima, S. J. dan A. Sunday. 2015. The role of information communication technology (ICT) in enhancing productivity in local government administration in Benue State, Nigeria. International Journal of Business and Economic Development (IJBED): 3(1).

Van de Ven, A. H. 1992. Suggestions for studying strategy process: A research note. Strategic management journal 13(5), 169-188.

Van de Ven, A. H. dan M. S. Poole. 1995. Explaining development and change in organizations. Academy of management review 20(3): 510-540.

Van de Ven, A. H. dan K. Sun. 2011. Breakdowns in implementing models of organization change. Academy of Management Perspectives 25(3): 58-74.

Welch, E. W. dan M. K. Feeney, M. K. 2014. Technology in government: How organizational culture mediates information and communication technology outcomes. Government information quarterly 31(4): 506-512.

Yang, C., Y. D. Wang, dan H. J. Niu. 2007. Does industry matter in attributing organizational learning to its performance?: Evidence from the Taiwanese economy. Asia Pacific Business Review, 13(4): 547-563.

Zeng, D., T. H. Ouyang, N. Zhou, dan J. Hu. 2015. The role of embeddedness in achieving IT-enabled organizational transformation: A case of Xi'an AeroEngine PLC (XAEP), China. International Journal of Information Management 35(5): 632-635.

Zikmund, W. G., S. D'Alessandro, H. Winzar, B. Lowe, dan B. Babin. 2017. Marketing Research: Asia-Pacific Edition: Cengage AU. 